\title{
Sensitivity of Neisseria gonorrhoeae to spectinomycin and thiamphenicol
}

\author{
K GRUNDER AND D PETZOLDT \\ From the Department of Dermatology and Venereology, University Medical School, Lübeck, \\ West Germany
}

SUMMARY Between 1966 and 1978 the sensitivities of strains of Neisseria gonorrhoeae (70-80 strains in each year) to penicillin, thiamphenicol, and spectinomycin were tested. For penicillin the proportion of less sensitive strains increased from $21 \%$ in 1976 to $41 \%$ in 1978 and for thiamphenicol from $10 \%$ to $18 \%$ over the same period. All the strains proved to be sensitive to spectinomycin. A significant correlation in the degree of sensitivity was observed between penicillin and thiamphenicol but not between penicillin and spectinomycin.

\section{Introduction}

All over the world strains of Neisseria gonorrhoeae have shown a steady reduction in sensitivity to penicillin. This situation demands the continued development of suitable alternatives for the treatment of gonorrhoea.

In 1976 in Lübeck the situation was relatively favourable with only $21 \%$ less sensitive strains $\left(\mathrm{IC}_{50}\right.$ $0.063 \mathrm{IU} / \mathrm{ml}$ ) (fig 1). ${ }^{1}$ In 1977 this proportion increased to $31 \%$ and in 1978 to $41 \%$; the graph shows the higher peaks moving to the right (fig 1). The increase in mean $50 \%$ concentration $\left(\mathrm{IC}_{50}\right)$ from $0.08 \mathrm{IU} / \mathrm{ml}$ to $0.19 \mathrm{IU} / \mathrm{ml}$ is significant $(t=3.4732$; $\mathrm{P}<0 \cdot 001$ ). Consequently, conditions here are now similar to those observed in other regions some years ago. ${ }^{23}$

Although the so-called less sensitive strains can still be treated with larger doses of penicillin, the limit of effectiveness of penicillin will be reached in a few years' time if this trend persists. In addition, there have been reports from a number of countries in the last three years of $\beta$-lactamase-producing strains with an absolute resistance to penicillin. ${ }^{4-15}$

For these reasons we have tested the sensitivity of strains isolated in the Lübeck area (preserved since 1976 in liquid nitrogen) to spectinomycin and thiamphenicol and compared the results with their sensitivity to penicillin.

\section{Materials and methods}

The sensitivity of strains to spectinomycin and thiamphenicol was determined by the plate dilution Address for reprints: Professor D Petzoldt, Universităts Hautklinik, Voßtrasse 2, D-6900 Heidelberg, West Germany

Received for publication 24 September 1979 method according to the directions of the WHO International Reference Centre for Gonococci in Copenhagen. ${ }^{16}$ The evaluation was performed by the Kärber method and a mean $\mathrm{IC}_{50}$ was calculated. ${ }^{16}$

\section{STATISTICAL ANALYSIS}

Student's $t$ test was used to compare differences of antibiotic sensitivity in the different years. Where correlations between two antibiotics were obvious we used the non-parametric graphical medial test, as described by Quenouille; ${ }^{17}$ where correlations were doubtful a rank correlation method with ties (Spearman) was performed. ${ }^{18}$

\section{Results}

The sensitivity of the strains to spectinomycin and thiamphenicol over the three-year period is shown in fig 2. Between 1976 and 1978 the mean $I_{50}$ of spectinomycin increased slightly but significantly from $7 \mu \mathrm{g} / \mathrm{ml}$ to $8.5 \mu \mathrm{g} / \mathrm{ml}(t=3.6608 ; \mathrm{P}<0.001)$. Although the peak remained at $10 \mu \mathrm{g} / \mathrm{ml}$ the percentage of strains sensitive to $10 \mu \mathrm{g} / \mathrm{ml}$ increased. None of the strains, including a $\beta$-lactamaseproducing strain imported from Manila and examined in our laboratory, exceeded the limit of $10 \mu \mathrm{g} / \mathrm{ml}$. Therefore all the strains must be regarded as highly sensitive. The asymmetrical distribution with the maximum peaks at the right side corresponds with the results of other studies. ${ }^{19-23}$

The mean $\mathrm{IC}_{50}$ of thiamphenicol increased significantly from $0.21 \mu \mathrm{g} / \mathrm{ml}$ to $0.34 \mu \mathrm{g} / \mathrm{ml}$ $(t=4.4188 ; \mathrm{P}<0.001)$; the peak shifted to the right approximately according to the penicillin distribution. The proportion of less sensitive strains increased from $10 \%$ in 1976 to $18 \%$ in 1978. In 1978, two strains had an $\mathrm{IC}_{50}$ of $1.41 \mu \mathrm{g} / \mathrm{ml}$ and must be 

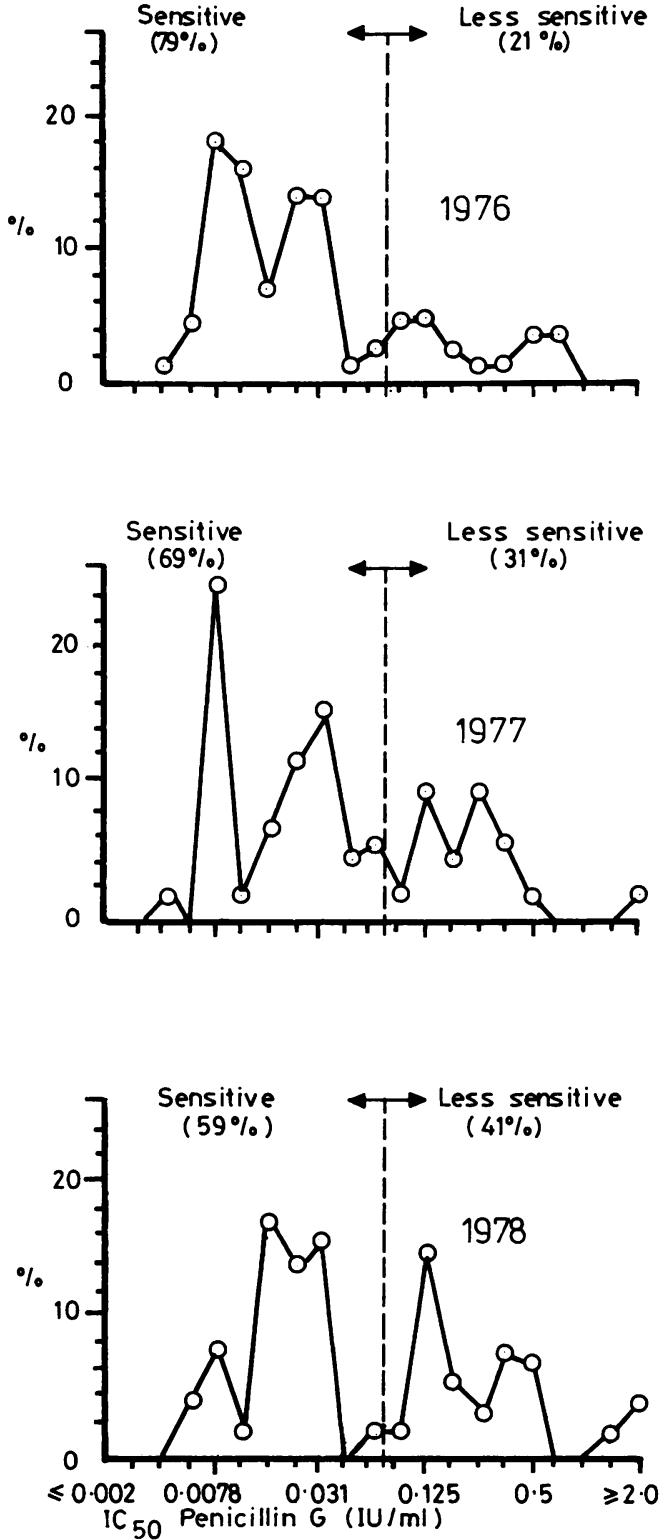

FIG 1 Sensitivity of strains of $N$ gonorrhoeae to penicillin in the Lübeck area in 1976, 1977, and 1978.

regarded as resistant (one of them was the $\beta$-lactamase-producing strain mentioned above).

The correlation of spectinomycin and thiamphenicol sensitivities with those of penicillin for all strains isolated in the three years with 228 pairs of observations are shown in fig 3 . The correlation with penicillin was not significant for spectinomycin but was significant for thiamphenicol, as also reported by other authors. ${ }^{20}$ Although the regression line on
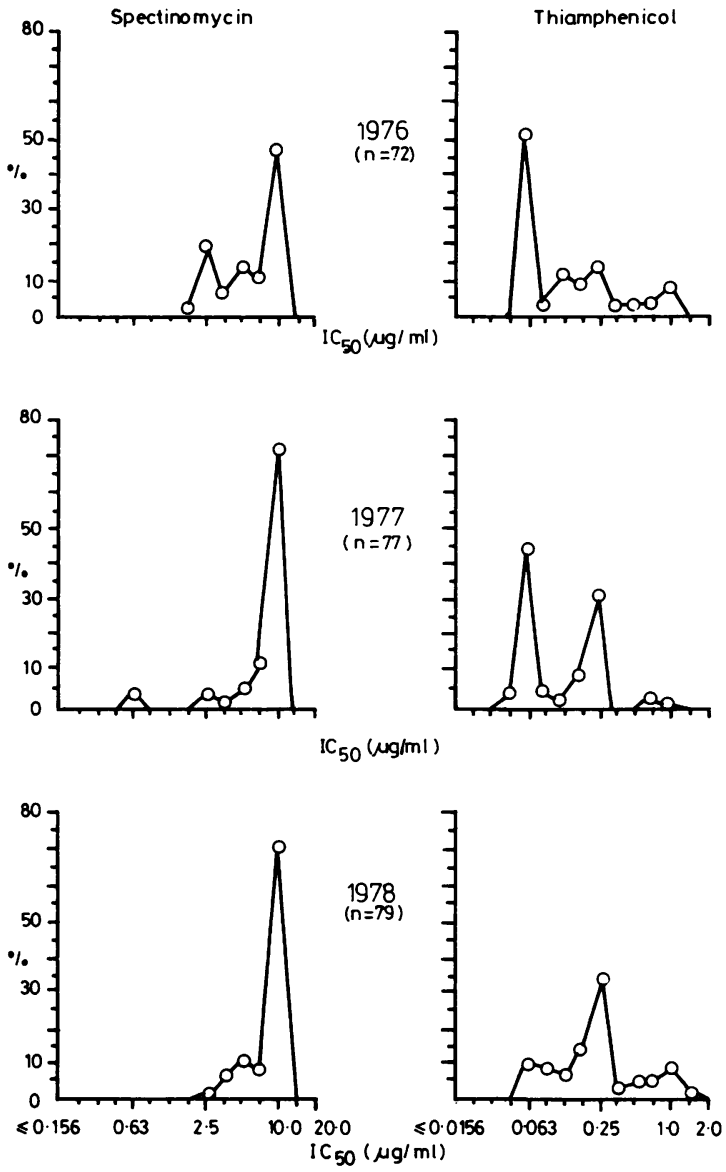

FIG 2 Sensitivity of strains of $\mathrm{N}$ gonorrhoeae to spectinomycin and thiamphenicol in the Lübeck area in 1976, 1977, and 1978.

the graph has visual impact, it is not quite correct since the values are not normally distributed. In the statistical evaluation of the correlation between penicillin and thiamphenicol we therefore used the non-parametric graphical medial test and found the correlation was significant at the $1 \%$ level.

The correlation between penicillin and spectinomycin proved not to be significant by Spearman's rank correlation with ties $\left(r_{S}^{*}=0 \cdot 024 ; 2 a\right.$ $>0 \cdot 1)$.

\section{Discussion}

Our investigation of the sensitivities of strains of $N$ gonorrhoeae to two alternative antibiotics showed that both were suitable in cases where penicillin treatment was unsuccessful or, for other reasons, impossible. 

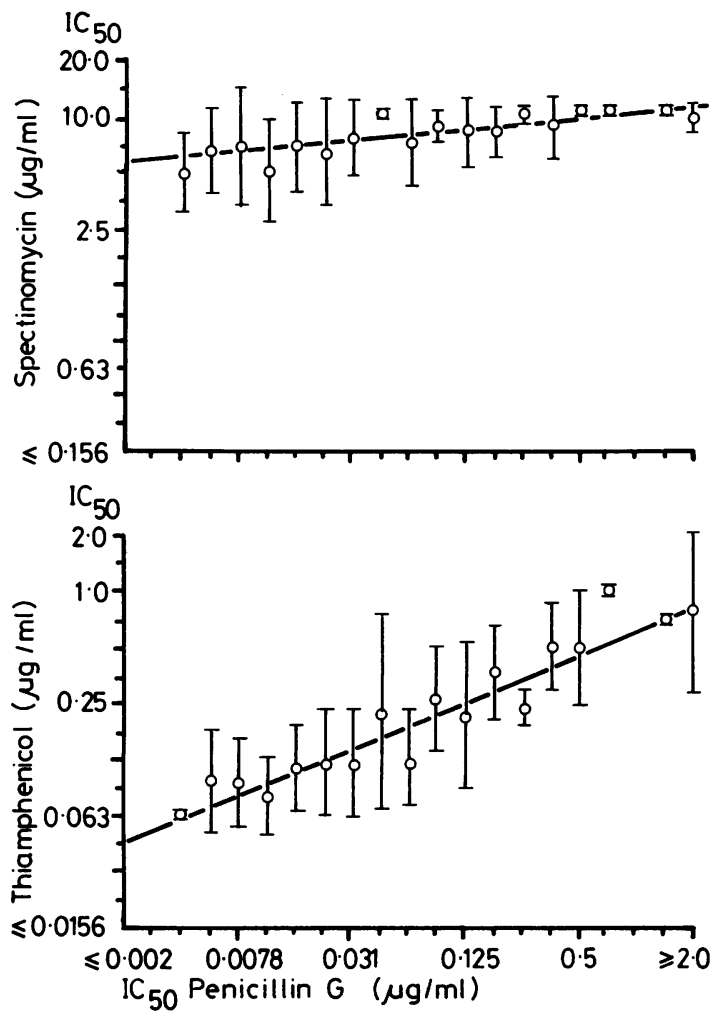

FIG 3 Correlation of sensitivities to spectinomycin and thiamphenicol with those to penicillin showing mean values with their standard deviation.

Sensitivity to thiamphenicol was significantly correlated with that to penicillin, but the proportion of less sensitive strains was significantly smaller $-8 \%$ for thiamphenicol compared with $41 \%$ for penicillin in 1978 .

In an appraisal of spectinomycin the following points should be considered:

(1) An increase of mean $\mathrm{IC}_{50}$ occurred during the three-year period, but it was insignificant.

(2) The proportion of less sensitive strains did not increase.

(3) The margin of therapeutic action is still considerable, assuming that the breakpoint for sensitive bacteria is $30 \mu \mathrm{g} / \mathrm{ml}$.

(4) Because the correlation with penicillin sensitivity was insignificant a marked change in the present favourable situation should not be expected in the near future.
Periodic investigation of sensitivity to spectinomycin is indicated, particularly to recognise an increasing resistance of the "one-step" type.

\section{References}

1. Gründer $\mathrm{K}$, Petzoldt D. Die penicillinempfindlichkeit von Neisseria gonorrhoeae im Lübecker Raum unter besonderer berücksichtigung etwaiger penicillinasebildner. Hautarzt 1977;28 suppl 2:87-90.

2. Petzoldt D, Reyn A. Die penicillinempfindlichkeit von Neisseria gonorrhoeae im Münchner Raum. Z Hautkr 1976; 51 suppl 2:115-9.

3. Petzoldt $\mathrm{D}$, Gründer $\mathrm{K}$, Neubert $\mathrm{U}$. Sensitivity of $N$ gonorrhoeae to penicillin in West Germany. $\mathrm{Br} J$ Vener Dis 1979; 55: 80-2.

4. Arya OP, Rees E, Percival A, Alergant CD, Annels EH, Turner GC. Some clinical-epidemiological facts of gonorrhoea due to penicillinase-producing strains in Merseyside. $\mathrm{Br} J$ Vener Dis 1978;54:28-35.

5. Arya OP, Percival A. Outbreak of gonorrhoea due to $\beta$-lactamase-producing gonococci in Liverpool: a short report. WHO/VDT/77415 1977; 1-7.

6. Ashford WA, Golash RG, Hemming VG. Penicillinaseproducing Neisseria gonorrhoeae. Lancet 1976; ii:657-8.

7. Hallet AF, Appelbaum PC, Cooper R, Mokgokong S, Monale D. Penicillinase-producing Neisseria gonorrhoeae from South Africa. Lancet $1977 ;$ i: 1205.

8. Milatović D, Machka K, Galla $O$, Braveny I $\beta$-lactamase bildende gonokokken in München. Infection 1978;6:242-3.

9. Neubert U, Ruckdeschel G. Isolierung penicillinasebildender gonokokken in München. Münch Med Wochenschr 1978; 120: 1063-4.

10. Percival A, Corkill JE, Arya OP, Rowlands J, Alergant CD, Rees E. Penicillinase-producing gonococci in Liverpool. Lancet 1976; ii: 1379-82.

11. Philips CW, Aller RD, Cohen NS. Penicillinase-producing Neisseria gonorrhoeae. Lancet 1976; ii: 960.

12. Philips J. $\beta$-lactamase-producing, penicillin-resistant gonococcus. Lancet 1976 ; ii: $656-7$.

13. Turner GC, Ratcliffe JG, Anderson D. Penicillinase-producing Neisseria gonorrhoeae. Lancet 1976; ii: 793.

14. Wilkinson $A E$, Seth $A D$, Rodin $P$. Infection with penicillinaseproducing gonococcus. $\mathrm{Br}$ Med $J$ 1976; ii: 1233.

15. Gründer K, Petzoldt D, Schoop HJ, Eidmann E. Erneutes auftreten penicillinasebildender Neisseria gonorrhoeae in Deutschland. Z Hautkr 1979;54:465-8.

16. Reyn A, Weis Bentzon M, Ericsson H. Comparative investigations of the sensitivity of $N$ gonorrhoeae to penicillin. Acta Path Microbiol Scand 1963;57:235-55.

17. Quenouille MH. Associated Measurements. London: Butterworth Press, 1952:37-40.

18. Kendall MG. Rank Correlation Methods, 3rd ed. London 1962:38-41.

19. Dillon JR, Eidus L, Diena BB. Cross-Canada survey of susceptibility of Neisseria gonorrhoeae to six antimicrobial agents. Can Med Assoc J 1978; 119:223-8.

20. Füllhaas I, Vischer WA, Brügger P, Rufli T. Antibiotic sensitivity of gonococcal strains isolated from patients in Basel and environs. Dermatologica 1979;158:249-56.

21. Levy I, Wicher K, Rose NR. In-vitro susceptibility of Neisseria gonorrhoeae to spectinomycin examined by a broth dilution method. Antimicrob Agents Chemother 1973;3:335-7.

22. Meheus A, Piot P, Patty S, van Dyck E, Vanden Berghe D. Activity in vitro of 10 antimicrobial agents against Neisseria gonorrhoeae. A study of the correlation between the sensitivities. Br J Vener Dis 1976; 52:329-32.

23. Meyer-Rohn J. Resistenzsituation von Neisseria gonorrhoeae gegenüber spectinomycin. Z Hautkr 1977;52 suppl 1:7-8. 